УДК 631.42.332.3

(C) 2012

Клименко М. О., кандидат технічних наук

Національний університет водного господарства та природокористування

\title{
СТАН ЗЕМЕЛЬНИХ РЕСУРСІВ БАСЕЙНУ РІЧКИ ГОРИНЬ
}

\section{Рецензент - кандидат сільськогосподарських наук А. М. Прищепа}

\begin{abstract}
Наведенні результати досліджень із вивчення агроекологічного стану земель сільськогосподарського призначення басейну річки Горинь за показниками екологічної стабільності, рівня антропогенного навантаження та стану агроландшафтів.

Установлено, щзо відносно задовільним станом характеризуються лише райони басейну, які відносяться до зони полісся, а найбільш вразливою і нестабільною є територія зони лісостепу, щзо перебуває у незадовільному та критичному екологічному стані, має підвищений рівень антропогенного навантаження, низьку екологічну стабільність $i$ високу трансформацію природних екосистем.
\end{abstract}

Ключові слова: басейн річки, коефічієнти економічної стабільності, антропогенного навантаження, оцінка стану агроландшафту.

Постановка проблеми. Однією 3 найбільш важливих проблем сьогодення стає використання земельних ресурсів на засадах сталого розвитку, що виключає поширення деградаційних процесів. Проте у процесі реформування сільськогосподарської галузі майже повсемісно виникає ситуація, що призводить до погіршення стану земельних ресурсів внаслідок порушення чергування сільськогосподарських культур, використання застарілих технологій без внесення органічних і мінеральних добрив і досить високого рівня розораності території.

Аналіз досліджень i публікацій, у яких започатковано розв'язання даної проблеми. Особливостями оцінки стану земель сільськогосподарського призначення $€$ використання комплексу показників, і насамперед коефіцієнтів екологічної стабільності, рівня антропогенного навантаження на земельні ресурси та ступеня порушення стану екологічної рівноваги у співвідношенні угідь. Основні дослідження 3 даної проблеми проводились у розрізі областей $[1-3,6$, $7,10]$, тоді як для стабілізації екологічного стану поверхневих вод річок слід приділити увагу вивченню перетворюваності агроландшафтів у межах басейну річок [4].

Мета і завдання досліджень. Мета досліджень полягала у вивченні та оцінці стану земельних ресурсів басейну р. Горинь. Основними завданнями було проведення комплексної оцінки земель сільськогосподарського призначення.

Методики досліджень. На основі даних обласних головних управлінь земельних ресурсів, інститутів землеустрою та обласних центрів «Облдержродючість» (Волинської, Житомирської, Рівненської, Тернопільської, Хмельницької областей) і статистичних щорічників, нами був здійснений аналіз стану земельних ресурсів у басейні р. Горинь $[2,8,9]$.

Аналіз проводився з використанням таких показників, як: 1) коефіцієнт екологічної стабільності:

$$
K_{e c}=\frac{\sum_{n}^{1} S i \cdot K i}{\sum_{n}^{1} S i},
$$

де: $\mathrm{S}_{\mathrm{i}}$ - площа угіддя i-виду, га; $\mathrm{n}$ - кількість показників; $\mathrm{K}_{\mathrm{i}}$ - коефіцієнт екологічних властивостей угідь і-виду (рілля - 0,14; лісосмуги 0,38 ; багаторічні насадження - 0,43 ; городи 0,50 ; сіножаті - 0,62; пасовища $-0,68$; ставки, болота - 0,79 ; ліси $-1,0)$;

2) критерій антропогенного тиску на довкілля:

$$
K_{a n}=\frac{\sum_{n}^{1} S i \cdot B i}{\sum_{n}^{1} S i}
$$

де: $\mathrm{S}_{\mathrm{i}}-\mathrm{S}_{\mathrm{n}}-$ площа угіддя 3 певним рівнем антропогенного навантаження; $\mathrm{n}$ - кількість показників; $5_{\mathrm{i}}-\mathrm{b}_{\mathrm{n}}-$ оціночні бали відповідних угідь (землі промислові, забудовані - 5 бал.; рілля, багаторічні насадження - 4 бал.; природні кормові угіддя - 3 бал.; лісосмуги, ліси, болота 2 бал.; природно-заповідний фонд - 1 бал).

Оцінку екологічного стану території здійснювали за показниками $\mathrm{K}_{\mathrm{ec}}$ та $\mathrm{K}_{\text {ан }}$ (табл. 1).

Екологічний стан агроландшафтів оцінювали за ступенем порушення рівноваги у співвідношеннях ріллі (Р), з іншого боку, - площ природних компонентів ландшафту (ЕСУ), які виконують екологостабілізуючу функцію. 


\section{1. Оцінка екологічного стану території за показником Кес та Кан}

\begin{tabular}{|c|c|c|c|}
\hline \multicolumn{2}{|c|}{ Коефіціснти } & \multirow{2}{*}{$\begin{array}{c}\text { Екологічна стабільність } \\
\text { території }\end{array}$} & $\begin{array}{c}\text { Рівень антропогенного } \\
\text { навантаження }\end{array}$ \\
\hline Кес & Кан & екологічно нестабільна & високий \\
\hline 0,33 & $4,1-5,0$ & слабо стабільна & підвищений \\
\hline $0,34-0,50$ & $3,1-4,0$ & середньо стабільна & середній \\
\hline $0,51-0,66$ & $2,1-3,0$ & екологічно стабільна & низький \\
\hline$\geq 0,67$ & $1,0-2,0$ & \multicolumn{2}{|c}{} \\
\hline
\end{tabular}

Результати досліджень. Розораність теритоpiї в Україні станом на 2010 рік становила $51,9 \%$, що обумовлено інтенсивним використанням земель у сільському господарстві (частина ріллі у землях сільськогосподарського призначення в Україні сягає 79,1\%). В останні десятиріччя спостерігається тенденція до зменшення площі ріллі у структурі сільськогосподарських угідь. На Поліссі площа ріллі зменшилась у 2010 р. на 5,7 \% у порівнянні з 1990 роком, а в Лісостепу України цей показник знизився на 4,4 \% [5]. Слід зазначити, що середньоєвропейський рівень розораності становить лише $27,9 \%$, а найвищий рівень розораності території має Данія (53\%) [5]. Тобто, в Європі дотримуються «трьох третин», а саме: дві третини території відведено під заповідники (зайнята природною рослинністю й територією, на якій допускається обмежене господарське використання зі збереженням природного ландшафту), і лише одна третина може бути використана у рільництві [2]. Водночас на території басейну р. Горинь, за даними обласних головних управлінь земельних ресурсів, (при загальній площі земель областей 1994,4-2987,9 тис. га) 46,82-77,1 \% займають сільськогосподарські угіддя, 13,86-40,18 \% - ліси та інші лісовкриті площі, 1,0-5,84\% - відкриті заболочені землі, 1,17-1,68 \% - відкриті землі без рослинного покриву, 0,52-1,76\% - інші землі, 163 -
2,25 \% - території, покриті водами (табл. 1).

У структурі сільськогосподарських угідь на ріллю припадає від 33,60 до 60,80\%, сіножаті та пасовища - 10,74-18,23\%, багаторічні насадження - 0,18-1,98\%, а на забудовані землі - від 2,54 до 4,00 \% (табл. 2).

Як видно з даних таблиці, територія Хмельницької області має високу розораність $(60,80 \%)$, що вказує на низьку стійкість природних ландшафтів і потребує при переході до збалансованого землекористування вирівнювання співвідношення між ріллею та природними угіддями.

У цілому по території басейну ситуація далеко неоднакова. Поскільки басейн річки Горинь охоплює дві природно-кліматичних зони (Полісся й Лісостеп), він характеризується значною розчленованістю рельєфу і специфічним меридіанним розподілом метеорологічних показників.

Установлено, що для земельних ресурсів басейну існує декілька типів кризових ситуацій, що обмежують можливості їхього збалансованого використання й які нерозривно пов'язані 3 поняттям стійкості геосистеми [2]. Основними серед них $є$ негативні наслідки широкомасштабних гідротехнічних меліорацій у зоні полісся, розвиток еродованості земель у зоні лісостепу та забруднення сільськогосподарських угідь радіонуклідами, зумовлене Чорнобильською катастрофою.

\section{2. Структура земельних угідь басейну р. Горинь}

\begin{tabular}{|c|c|c|c|c|c|c|c|c|c|c|c|}
\hline \multirow[b]{2}{*}{ Назва області } & \multicolumn{11}{|c|}{ \% від загальної площі } \\
\hline & $\begin{array}{c}\text { загальна } \\
\text { площа, га }\end{array}$ & $\begin{array}{c}\text { сіль- } \\
\text { сько- } \\
\text { госпо- } \\
\text { дарсь- } \\
\text { кі }\end{array}$ & рілля & $\begin{array}{c}\text { бага- } \\
\text { торіч- } \\
\text { ні } \\
\text { наса- } \\
\text { джен- } \\
\text { ня }\end{array}$ & $\begin{array}{c}\text { сіно- } \\
\text { жаті } \\
\text { та па- } \\
\text { сови- } \\
\text { ща }\end{array}$ & $\begin{array}{c}\text { ліси і } \\
\text { лісо- } \\
\text { по- } \\
\text { криті } \\
\text { площі }\end{array}$ & $\begin{array}{c}\text { забу- } \\
\text { довані } \\
\text { землі }\end{array}$ & $\begin{array}{c}\text { забо- } \\
\text { лочені } \\
\text { землі }\end{array}$ & $\begin{array}{c}\text { землі } \\
\text { без } \\
\text { рос- } \\
\text { лин- } \\
\text { ного } \\
\text { по- } \\
\text { криву }\end{array}$ & води & $\begin{array}{c}\text { інші } \\
\text { землі }\end{array}$ \\
\hline Хмельницька & 2062878,5 & 76,1 & 60,80 & 1,98 & 13,19 & 13,86 & 4,09 & 1,0 & 1,17 & 2,04 & 1,76 \\
\hline Рівненська & 1994400 & 46,82 & 34,83 & 0,18 & 11,36 & 40,18 & 2,74 & 5,29 & 1,68 & 2,16 & 0,64 \\
\hline Житомирська & 2987942,8 & 51,11 & 36,57 & 0,67 & 10,74 & 37,07 & 2,98 & 3,32 & 1,27 & 1,63 & 0,65 \\
\hline Волинська & 2002169 & 53,40 & 33,60 & 0,50 & 18,23 & 34,67 & 2,54 & 5,81 & & 2,25 & 0,52 \\
\hline Тернопільська & 1382473 & 75,92 & 61,78 & 1,09 & 12,52 & 14,50 & 4,48 & 0,40 & 1,30 & 1,41 & 1,50 \\
\hline
\end{tabular}




\section{СІЛЬСЬКЕ ГОСПОДАРСТВО. РОСЛИННИЦТВО}

Зменшити негативні наслідки екстенсивного землекористування можна шляхом оптимізації структури сучасних сільськогосподарських ландшафтів на території басейну річки Горинь. Як засвідчує аналіз та оцінка екологічного балансу у співвідношенні основних типів угідь, територія басейну характеризується значною розораністю. У поліській частині басейну розораність коливається в межах від 9,74 до 67,0\%, а у лісостеповій - від 50,66 до 79,0 \%.
За результатами оцінки екологічного стану сільськогосподарських ландшафтів, здійсненої за співвідношенням ріллі (Р) до сумарної площі екологічно-стабільних угідь (ЕСУ), на території басейну виділено 5 екотипів територій $з$ екологічним станом - від оптимального до критичного.

Оптимальне співвідношення площ у 2009 році ріллі та екологічно-стабільних угідь (0-й екотип) характерний для чотирьох районів зони полісся: Зарічненського, Костопільського, Рокитнівського

\section{3. Встановлення екологічної стабільності та рівня антропогенного навантаження}

на території басейну р. Горинь

\begin{tabular}{|c|c|c|c|c|c|}
\hline $\begin{array}{c}\text { № } \\
\text { П/ா }\end{array}$ & Назва району & $\begin{array}{l}\text { Коефіцієнт еко- } \\
\text { логічної стабі- } \\
\text { льності Кес }\end{array}$ & $\begin{array}{c}\text { Екологічна } \\
\text { стабільність } \\
\text { території }\end{array}$ & $\begin{array}{c}\text { Коефіцієнт ан- } \\
\text { тропоген. нава- } \\
\text { нтаження Кан }\end{array}$ & $\begin{array}{c}\text { Рівень антропо- } \\
\text { генного наванта- } \\
\text { ження }\end{array}$ \\
\hline \multicolumn{6}{|c|}{ зона Полісся } \\
\hline 1 & Білогірський & 0,34 & слаб. стаб. & 3,59 & підвищений \\
\hline 2 & Ізяславський & 0,46 & слаб. стаб. & 3,32 & підвищений \\
\hline 3 & Полонський & 0,43 & слаб. стаб. & 3,38 & підвищений \\
\hline 4 & Славутський & 0,43 & слаб. стаб. & 3,39 & підвищений \\
\hline 5 & Шепетівський & 0,52 & серед. стаб. & 3,03 & підвищений \\
\hline 6 & Березнівський & 0,79 & екол. стаб. & 2,63 & середній \\
\hline 7 & Володимерецький & 0,78 & екол. стаб. & 2,18 & середній \\
\hline 8 & Дубровицький & 0,75 & екол.стаб. & 2,69 & середній \\
\hline 9 & Зарічненський & 0,77 & екол. стаб. & 2,06 & середній \\
\hline 10 & Костопільський & 0,84 & екол. стаб. & 2,51 & середній \\
\hline 11 & Рокитнівський & 0,87 & екол. стаб. & 2,32 & середній \\
\hline 12 & Сарненський & 0,77 & екол. стаб. & 2,65 & середній \\
\hline 13 & Баранівський & 0,23 & екол. нестаб. & 2,98 & середній \\
\hline 14 & Ємільчинський & 0,64 & серед. стаб. & 1,90 & низький \\
\hline 15 & Червоноармійський & 0,43 & слаб. стаб. & 3,30 & підвищений \\
\hline 16 & Романівський & 0,51 & серед. стаб. & 3,10 & підвищений \\
\hline 17 & Новоград-Волинський & 0,59 & серед. стаб. & 3,00 & середній \\
\hline 18 & Ківерцівський & 0,66 & серед. стаб. & 2,89 & середній \\
\hline 19 & Маневицький & 0,78 & екол. стаб. & 2,60 & середній \\
\hline \multicolumn{6}{|c|}{ зона Лісостепу } \\
\hline 1 & Волочиський & 0,26 & екол. нестаб. & 3,77 & підвищений \\
\hline 2 & Красилівський & 0,31 & екол. нестаб. & 3,68 & підвищений \\
\hline 3 & Старокостянтинівський & 0,28 & екол. нестаб. & 3,73 & підвищений \\
\hline 4 & Старосиневський & 0,27 & екол. нестаб. & 3,76 & підвищений \\
\hline 5 & Теофіпольський & 0,26 & екол. нестаб. & 3,81 & підвищений \\
\hline 6 & Гощанський & 0,47 & слаб. стаб. & 3,71 & підвищений \\
\hline 7 & Дубенський & 0,58 & серед. стаб. & 3,35 & підвищений \\
\hline 8 & Здолбунівський & 0,56 & серед. стаб. & 3,43 & підвищений \\
\hline 9 & Корецький & 0,52 & серед. стаб. & 3,56 & підвищений \\
\hline 10 & Млинівський & 0,50 & слаб. стаб. & 3,62 & підвищений \\
\hline 11 & Острозький & 0,60 & серед. стаб. & 3,28 & підвищений \\
\hline 12 & Рівненський & 0,56 & серед. стаб. & 3,42 & підвищений \\
\hline 13 & Любарський & 0,27 & екол. нестаб. & 3,72 & підвищений \\
\hline 14 & Чуднівський & 0,35 & слаб. стаб. & 3,51 & підвищений \\
\hline 15 & Збаражський & 0,29 & екол. нестаб. & 3,76 & підвищений \\
\hline 16 & Кременецький & 0,41 & слаб. стаб. & 3,51 & підвищений \\
\hline 17 & Лановецький & 0,30 & екол. нестаб. & 3,75 & підвищений \\
\hline 18 & Шумський & 0,49 & слаб. стаб. & 3,34 & підвищений \\
\hline
\end{tabular}


та Маневицького, в яких розораність не перевищувала $19,71 \%$. Території інших семи районів цієї зони мають добрий стан агроландшафтів i відносяться до 1-го, досить стійкого екотипу, в яких відсоток ріллі коливається у межах від 21,72 до $32,2 \%$. Задовільний стан (2-й екотип) мають 3 райони, а незадовільний (3-й екотип) сформувався у трьох районах із відсотком ріллі від 56,72 до $67 \%$. На території басейну, що відноситься до зони лісостепу, стан агроландшафтів оцінюється від задовільного до критичного. До того ж мало змінений, а відтак, стійкий агроландшафт (2-й екотип) має лише Острозький район $(50,66 \%)$, тоді як на територіях інших районів цієї зони сформувалися агроландшафти 3 незадовільним i кризовим екологічним станом
(3 і 4-й екотипи), процент розораності яких становить понад $56 \%$ і досягає в окремих районах $79 \%$. Розораність понад двох третин погіршує не лише стійкість агроландшафтів басейну річки, але й $є$ першопричиною погіршання екологічного стану поверхневих вод приток і річки Горинь.

Водночас слід зазначити, що висока розораність сільськогосподарських угідь (до двох третин) може суттєво погіршувати екологічну стабільність територій як окремих районів, так i території басейну в цілому. Так, за розрахунками коефіцієнтів екологічної стабільності територій $(К е c)$ та антропогенного навантаження (Кан) на земельні ресурси, найвищу екологічну стабільність мають райони зони полісся (табл. 3).

\section{4. Оцінка екологічного стану агроландиафтів басейну р. Горинь за співвідноченням угідь}

\begin{tabular}{|c|c|c|c|c|c|}
\hline № п/п & Назва району & $\begin{array}{c}\text { Відсоток ріллі, } \\
\%\end{array}$ & $\begin{array}{c}\text { Відсоток екологостабіль- } \\
\text { них угідь, \% }\end{array}$ & $\begin{array}{c}\text { Стан } \\
\text { агроландшафтів } \\
\end{array}$ & Екотип \\
\hline & & \multicolumn{4}{|c|}{ зона Полісся } \\
\hline 1 & Білогірський & 67,00 & 33,00 & незадовіл. & III \\
\hline 2 & Ізяславський & 53,71 & 46,29 & задовіл. & II \\
\hline 3 & Полонський & 56,72 & 43,29 & незадовіл. & III \\
\hline 4 & Славутський & 58,80 & 41,20 & незадовіл. & III \\
\hline 5 & Шепетівський & 47,21 & 52,79 & задовіл. & II \\
\hline 6 & Березнівський & 21,72 & 78,28 & добрий & $\mathrm{I}$ \\
\hline 7 & Володимерецький & 22,23 & 77,77 & добрий & $\mathrm{I}$ \\
\hline 8 & Дубровицький & 22,64 & 77,36 & добрий & I \\
\hline 9 & Зарічненський & 19,71 & 80,29 & оптимальн. & 0 \\
\hline 10 & Костопільський & 18,22 & 80,78 & оптимальн. & 0 \\
\hline 11 & Рокитнівський & 9,74 & 90,26 & оптимальн. & 0 \\
\hline 12 & Сарненський & 20,49 & 79,51 & добрий & I \\
\hline 13 & Баранівський & 34,71 & 65,29 & добрий & I \\
\hline 14 & Ємільчинський & 32,30 & 67,70 & добрий & $\mathrm{I}$ \\
\hline 15 & Радивилівський & 52,81 & 47,19 & задовільн. & II \\
\hline 16 & Романівський & 41,31 & 58,69 & добрий & II \\
\hline 17 & Новоград-Волинський & 35,20 & 64,80 & добрий & I \\
\hline 18 & Ківерцівський & 31,00 & 69,00 & добрий & I \\
\hline 19 & Маневицький & 17,00 & 83,00 & оптимальн. & 0 \\
\hline & & \multicolumn{4}{|c|}{ зона Лісостепу } \\
\hline 1 & Волочиський & 78,29 & 21,71 & критичн. & IV \\
\hline 2 & Красилівський & 73,70 & 26,30 & критичн. & IV \\
\hline 3 & Старокостянтинівський & 77,81 & 22,19 & критичн. & IV \\
\hline 4 & Старосиневський & 78,00 & 22,00 & критичн. & IV \\
\hline 5 & Теофіпольський & 79,00 & 21,00 & критичн. & IV \\
\hline 6 & Гощанський & 74,13 & 25,87 & критичн. & IV \\
\hline 7 & Дубенський & 56,83 & 43,17 & незадовіл. & III \\
\hline 8 & Здолбунівський & 60,47 & 39,53 & незадовіл. & III \\
\hline 9 & Корецький & 68,10 & 31,90 & незадовіл. & III \\
\hline 10 & Млинівський & 73,16 & 26,84 & критичн. & IV \\
\hline 11 & Острозький & 50,66 & 49,34 & задовільн. & II \\
\hline 12 & Рівненський & 60,99 & 39,01 & незадовіл. & III \\
\hline 13 & Любарський & 76,22 & 23,78 & критичн. & IV \\
\hline 14 & Чуднівський & 64,19 & 35,81 & незадовіл. & III \\
\hline 15 & Збаражський & 76,40 & 23,60 & критичн. & IV \\
\hline 16 & Кременецький & 61,48 & 38,52 & незадовіл. & III \\
\hline 17 & Лановецький & 74,75 & 25,25 & критичн. & IV \\
\hline 18 & Шумський & 51,07 & 48,93 & задовільн. & II \\
\hline
\end{tabular}


Як свідчать дані таблиці 3, за значеннями коефіцієнтів екологічної стабільності у цій зоні виявлено 8 районів, які відносяться до екологічно стабільних, 3 - середньо стабільних, 5 - слабко стабільних та 1 - із екологічно нестабільним станом території. За показником рівня антропогенного навантаження райони зони полісся відносяться до трьох категорій, а саме: низького (Смільчинський - 1,9); середнього антропогенного навантаження (10 районів); та підвищеного (6 районів). Максимальні значення Кан $(3,59)$ встановлені для Білогірського району. Для районів зони лісостепу виявлено три типи екологічної стабільності територій, а саме: середньо стабільних; слабко стабільних та екологічно нестабільних. Сім районів характеризується середньо стабільним станом територій із коливанням Кес від 0,60 до 0,51. Три інших райони (Гощанський $-0,47$, Млинівський $-0,50$, Чуднівський $-0,35$ ) відносяться до слабко стабільних. Інші шість районів даної зони відносяться до категорії екологічно нестабільного стану територій із показниками Кес менше ніж 0,33.

Збільшення розораності земель (понад третину) у районах зони лісостепу зумовило не лише зниження екологічної стабільності територій, але

\section{БІБЛІОГРАФІЯ}

1. Бахмат М. І., Кирилюк Б. В., Музика М. В. [ma iн.]. Проблеми моніторингу та стан земельних ресурсів Хмельницької області // Зб. наук. праць. - Вип. 15. - Т. 1. - Кам'янець-Подільський, 2007. - С. 3-8.

2. Земельні ресурси України / За ред. В. В. Медведєва, Т. Т. Лактіонової. - К.: Аграрна наука, 1998. - $150 \mathrm{c}$.

3. Клементова Б. Оценка экологической устойчивости сельськохозяйственного ландшафта/ Клементова Б. // Мелиорация и водное хозяйство. - 1995. - № 5. - С. 33-34.

4. Клименко М. О., Вознюк Н. М. Екологічний стан української генетики Єврорегіону «Буг»: Монографія. - Рівне: НУВГП, 2007. - 203 с.

5. Мельничук Д. О., Рідей Н. М., Тонха О. К. [ma ін.]. Актуальні проблеми стану земель сільськогоподарського призначення в Україні // Зб. наук. праць. - Вип. 15. - Т. 1. - Кам'янецьПодільський, 2007. - С. 13-16.

6. Методичні рекомендації з комплексної агро- й підвищення рівня антропогенного навантаження на їхній території.

За розрахунками рівня антропогенного навантаження всі райони зони лісостепу відносяться до категорії 3 підвищеним рівнем антропогенного навантаження, коли їхні Кан перевищують значення 3,1 (табл. 4).

Висновки. Сучасний стан земельних ресурсів басейну річки Горинь, особливо сільськогосподарських угідь, не забезпечує збалансованого природокористування внаслідок високої (понад третину) розорюваності території. Оцінка екологічного стану басейну річки Горинь, здійснена за складом і співвідношенням угідь, дала змогу районувати в іiі межах території, що різняться за показниками екологічної стабільності, рівня антропогенного навантаження та екологічного стану агроландшафтів. Установлено, що відносно задовільним станом характеризуються лише райони басейну, які відносяться до зони полісся, а найбільш вразливою й нестабільною є територія зони лісостепу, що перебуває у незадовільному та критичному екологічному стані, - має підвищений рівень антропогенного навантаження, низьку екологічну стабільність і високу трансформацію природних екосистем.

екологічної оцінки земель сільськогосподарського призначення / За ред. О. О. Ракоїд. - К.: Логос, 2008. $-51 \mathrm{c}$.

7. Методичні рекомендації оцінки екологічної стабільності агроландшафтів та сільськогосподарського землекористування / Третяк А. М., Третяк Р. А., Шквир М. І. - К., Ін-т Землеустрою УААН, 2001. $-15 \mathrm{c}$.

8. Статистичний щорічник «Сільське господарство України» за 2005 рік / Державний комітет статистики України: під заг. кер. Ю. М. Остапчука. - К., 2006. - 314 с.

9. Черняга П. Г., Мошинський В. С. Принципи і типи сучасного моніторингу земельних ресурсів // Зб. наук. праць. - Вип. 15. - Т. 1. - Кам'янецьПодільський, 2007. - С. 9-12.

10. Юхновський В. Ю. Лісоаграрні ландшафти рівнинної України: оптимізація, нормативи, економічні аспекти. - К., Інститут аграрної економіки, 2003. -273 с. 